\title{
FK506-Binding Protein-Like
}

National Cancer Institute

\section{Source}

National Cancer Institute. FK506-Binding Protein-Like. NCI Thesaurus. Code C97259.

FK506-binding protein-like (349 aa, $38 \mathrm{kDa}$ ) is encoded by the human FKBPL gene. This protein plays a role in the stabilization of cyclin-dependent kinase inhibitor 1 protein. 